\title{
Why Do We Work More Than Keynes Expected?
}

\section{Citation}

Freeman, Richard B. 2008. Why Do We work More than Keynes Expected? In Revisiting Keynes: Economic Possibilities for Our Grandchildren, ed. Lorenzo Pecchi and Gustavo Piga, 135-142. Cambridge: MIT Press.

\section{Published Version}

doi:10.7551/mitpress/9780262162494.003.0010

\section{Permanent link}

http://nrs.harvard.edu/urn-3:HUL.InstRepos:34310002

\section{Terms of Use}

This article was downloaded from Harvard University's DASH repository, and is made available under the terms and conditions applicable to Open Access Policy Articles, as set forth at http:// nrs.harvard.edu/urn-3:HUL.InstRepos:dash.current.terms-of-use\#OAP

\section{Share Your Story}

The Harvard community has made this article openly available.

Please share how this access benefits you. Submit a story.

Accessibility 


\section{Why Do We work More than Keynes Expected?}

\section{Richard B. Freeman Harvard University}

When a rich man doesn't want to work. He's a bon vivant. Yes, he's a bon vivant. But when a poor man doesn't want to work, He's a laugher, he's a lounger he's a lazier good for nothing He's a jerk!

(E.Y. Harburg, Finian's Rainbow "When the Idle Poor Become the Idle Rich")

Pondering the increase in income per head of $2 \%$ or so per year in the UK and other advanced countries for a century or so, which thanks to the power of compound interest raised incomes eight fold, Keynes foresaw a future world free from economic cares. He predicted that incomes would increase massively in the next 100 years and that the higher standard of living would produce an unparalleled era of leisure, where humans would work "three hour shifts or a fifteen hour week" and “do more things for ourselves ... only too glad to have small duties and tasks and routines.” Keynes's grandchildren would be bon vivants not good for nothing jerks because they would rich, but unlike the rich loungers of his era, whom Keynes felt "failed disastrously ... (because they had ) no associations or duties or ties" the people of 2030 would lead more meaningful lives, doing a modicum of useful work as well as other morally desirable activities. ${ }^{1}$

Keynes was right about the rise in incomes. Compound interest at $2.1 \%$ per year produces a eightfold gain in incomes. As a result, Keynes's grandchildren have much higher living standards than Keynes' generation: home computers, the Internet, cars, color TVs, huge medical advances, central heating (even in the UK), cheap airfare travel to anywhere in the world, and so on. But Keynes was wrong in thinking that this improvement in living standards would lead us to greatly reduce our hours and spend more time doing small household or leisure tasks. To be sure, hours worked among employed persons declined for much of the $20^{\text {th }}$ century but hours then stabilized toward the end of the

\footnotetext{
${ }^{1}$ Keynes, John Maynard “Economic Possibilities for our Grandchildren” p 5
} 
period at levels far above the fifteen hour work week that Keynes envisaged. ${ }^{2}$ In every country, the proportion of women working in the labor market rose greatly. In the US the result was that between 1970 and 2005, hours worked per adult in the labor market increased by 10\% while hours worked per adult in the household dropped. ${ }^{3}$ A similar pattern occurred in the UK in the 1980s and 1990s. Moreover, in the US and UK, where individuals have great leeway in choosing hours and where earnings inequality gives workers great incentive to put in long hours, ${ }^{4}$ hours worked far exceeded hours worked in continental countries such as France or Germany, where union policies and legal institutions limit hours worked and where earnings inequality is much lower.

${ }^{2}$ In 2005 hours per week in the US averaged 34.7 while those in Germany, which had one of the lowest hours worked, averaged.27.6 hours. Calculated from annual hours worked from OECD Employment Outlook 2006, table F.

${ }^{3}$ Between 1970 and 2005 US hours worked per worker fell by1 \% but the employment rate rose by $12 \%$ so hours per adult went up by about $11 \%$. Data from OECD Employment Outlook 2006 and Employment Outlook 1985.

${ }^{4}$ Higher inequality in earnings creates an incentive to work long hours whenever the additional hours worked increases an individual's chance of being promoted and thus rising in the highly unequal wage distribution or maintaining employment during a period of layoffs. See Bell, Linda A. \& Freeman, Richard B., 2001, "The incentive for working hard: explaining hours worked differences in the US and Germany," Labour Economics, Elsevier, vol. 8(2), pages 181-202, May 
The US is the most striking counter-example to Keynes' prediction that increased wealth would produce greater leisure. The US has $30 \%$ to $40 \%$ higher GDP per capita than France and Germany, but employed American work 30\% more hours over the year than employed persons in those countries. Since the US also has a higher proportion of the adult population employed than France, Germany, and most other EU countries, the average American adult works $40 \%$ more over the year than the average European adult. Americans are so committed to work that they don't take four vacation days from the two weeks that they typically receive, whereas Europeans take almost all of their 4-5 week vacations. And more Americans than Europeans say that they want to increase hours worked than to decrease hours worked at given wage rates 5 .

The decision of Keynes's grandchildren to work so much is associated with a reversal of what had been an historic inverse relation between hours and pay. In past decades, the poor have worked more than the rich. They had to work long and hard to feed themselves and their families. Work or perish. The rich, by virtue of their land holdings or hereditary position in society could be idle if that was their fancy. The phrase idle rich had real meaning.

In the latter half the $20^{\text {th }}$ century, the inverse relation between hourly pay and hours worked reversed itself, at least in the US. ${ }^{6}$ The workaholic rich replaced the idle rich. Those earning higher pay worked more hours than those earning lower pay. There are surely persons of great wealth who contribute nothing to the national product and persons who gain wealth through criminal work. But the typical high earner sits at the top of the earnings distribution by working a lot on something that society values. The problem for the highly paid today is not that of finding a modest amount of work to fulfil what Keynes called "the old Adam" in human nature of wanting to do something useful, but of finding

\footnotetext{
${ }^{5}$ Freeman, Richard America Works: the exceptional labor market, Russell Sage, 2007, chapter 4 ${ }^{6}$ Chinhui Juhn; Kevin M. Murphy; Robert H. Topel; Why has the Natural Rate of Unemployment Increased over Time?, pp. 75-142 Brookings Papers on Economic Activity, Vol. 1991, No. 2, 1991
} 
ways to reduce pressures to work more. And, higher living standard or not, the problem for the low paid is to find sufficient work to earn a decent living. For the low paid it is a matter both of obtaining the money necessary to buy what has become normal consumer goods in modern society, such as televisions, washing machines, cars, cell phones, and computers, and so on, but also having a sufficient buffer in income to enable them to pay the rent, heating bills, and in the US, medical expenses, as well as put money away for retirement, even in an economic downturn ${ }^{7}$.

Why did Keynes miss the boat on work?

He missed the boat by failing to appreciate the power of economic incentives to induce people, even those with high standards of living, to work long and hard. He did not expect that the increased cost of leisure due to rising wages would dominate the income effect that induces people to take more leisure. This was nothing peculiar in his expectation. Until the latter part of the $20^{\text {th }}$ century, when it became clear that people were not going to reduce hours greatly as income rose, most economists believed that the income effect was more powerful than the substitution effect. Textbooks often displayed backward bending labor supply curves in illustrate the point. But the race between the substitution and income effects turned out to be more of a fair race than a lock from your local tote. Among women, the substitution effect due to higher wages for women dominated the income effect arising from the higher income of their spouses, leading many women to leave the household to work in the market. Among men, substitution effects greatly influenced the timing of retirements, and appear to have become dominant in decisions about hours worked, at least in conjunction with the increased inequality and tournament style economic system that gives the person who puts in an extra hour of work to do better a potentially high return - all of which outmodes the traditional textbook

${ }^{7}$ For an analysis of what poverty means in a high income country with only a limited welfare state, see Maya Federman, Thesia I. Garner, Kathleen Short, W Bowman Cutter IV, John Kiely, David Levine, Duane McDough, and Marilyn McMillen” What does it mean to be poor in America?" Monthly Labor 
representation of labor supply as a backward bending relation.

Two other factors have enhanced the impact of the substitution effect on work. The first is the increase in inequality which was most pervasive in the US but which occurred in other advanced countries as well. Greater inequality enlarges the earnings gap between greater/lesser success in the market and thus gives workers more incentive to work long hours to succeed. Inequality, after all, involves not only a more uneven distribution of earnings, which most citizens view as undesirable, but also greater incentives to rise in the earnings distribution through hard work. If everyone is paid more or less the same, there is little pecuniary reason to put in more hours to gain a promotion or otherwise advance at work. By contrast, if pay varies greatly, there is a sizable incentive to do what it takes to climb up the earnings distribution, including putting in long hours. Empirically, advanced countries with higher inequality exhibit greater hours worked and a greater desire by the population to work more hours. In the US workers in occupations with high inequality work more hours than those in occupations with low inequality ${ }^{8}$.

The second factor enhancing the substitution effect is the rise of performance related compensation systems. Piece rate pay has declined in manufacturing due to the advent of assembly line and team-based modes of production which make it difficult to ascertain the productivity of individual workers, but in many lines of work firms pay workers individual bonuses. Commissions are common in sales jobs. Many firms base wage increases on supervisors' evaluations of individual performance. Tournament reward systems, in which the firm promotes the best performers over their peers, are widespread. Experiments with tournament modes of pay show that increased inequality

Review, May 1996, Vol. 119, No. 5

${ }^{8}$ Bell, Linda and Richard Freeman "Working Hard," in Gina Wong and Garnett Picot, Working Time in Comparative Perspective,Upjohn Institute, 2001 
produces more effort up to point. ${ }^{9}$ By analogy, increased inequality may also contribute to hours worked.

Two other factors that Keynes did not foresee have also increased work time. The advent of the computer and Internet make it easier for many people to work away from their offices. In 200410.2 million American workers reported that they did unpaid work at home in addition to paid work at their workplace. These workers averaged 6.8 hours of additional work - essentially an extra day for which they are not reimbursed beyond their normal pay. ${ }^{10}$ With email and digitalization of white-collar work, it is easy to do some work-related tasks at home or after hours. The incentive for putting in the extra time is that by completing or improving projects, employees can increase their chances of being promoted or keeping their job if the firm has to lay off workers. In an economy with considerable income inequality and a low social safety net, these are sizable income incentives.

The competitive pressure that globalization places on workers also operates to induce longer hours worked. The spread of modern technology and education has created a world where low wage workers in developing countries, most prominently China and India, are competitive with workers in advanced countries in ways that were unimaginable when Keynes wrote. Multinational firms can pressure workers in advanced countries to work longer or harder or at reduced wages because firms have an ample supply of low wage labor in developing countries that can do much of the work. In the domestic economy, immigrants often work long hours to succeed, and immigration has been increasing rapidly even in traditional emigrant-sending European countries. Off shoring of work based on modern technology and communication further allows firms to move jobs readily to low wage sites.

As a sign of the global pressures for workers in advanced countries to keep their nose to the

\footnotetext{
${ }^{9}$ Freeman, Richard and Alex Gelber, “Optimal Inequality/Optimal Incentives: evidence from a tournament” NBER WP 12588, Oct 2006

${ }^{10}$ US Bureau of Labor Statistics "Work at Home in 2004" USDL 05-1768, Sept 22, 2005 http://www.bls.gov/news.release/homey.nr0.htm
} 
grindstone, in 2006 Germany's IG Metall Union, which had been in the forefront of bargaining for reduced hours of work in the German automobile industry, agreed to extend its 29 hour work week to upwards of 33/34 hours a week at Volkswagen without any pay rise. In return the firm committed itself to invest in German plants and to maintain production there. Absent the agreement Volkswagen would have laid workers off and shifted production to lower wage countries. ${ }^{11}$ What is most surprising about Keynes' treatment of work in his essay is not his incorrect prediction that higher incomes would cause a huge drop in time worked, but his general disparagement of working overall. Using the Professor in Lewis Carroll's little known Sylvie and Bruno, Keynes mocked the purposive man who invests in the future as seeking "jam tomorrow and never jam today". He attributed this behavior to "the habits and instincts of the ordinary man, bred into him for countless generations", which creates a desire for work and an excessively low discount rate in assessing the present vs the future. In a world facing climate change and human destruction of the environment, the idea that people give too much weight to the future and not enough to the present in decisions seems well ... misplaced, to be it mildly. Rather than mocking purposive man with the passage from Sylvie and Bruno, Keynes would have done better to pay attention to the Invisible Hand version of the Lobster Quadrille from Alice in Wonderland. Let me remind you of this passage, which seems apropos to the world of Keynes' grandchildren ${ }^{12}$ :

Will you work a little longer?" said the supervisor to the staff, There's a new firm close behind us doing time and a half. Low paid foreign labor threatens to win the market race! We must put in more hours or else we'll lose our place! Will you, won't you, will you, won't you, put in extra time? Will you, won't you, will you, won't you, do more for your dime?

There is another shore, you know, upon the other side. Where the socially excluded and unemployed reside The further off from England the nearer is to France It's your future, staff, unless you come and join the dance.

\footnotetext{
${ }^{11} \mathrm{http} / / / \mathrm{www}$. politicalgateway.com/news/read/39278

${ }^{12}$ Adapted from Lewis Carroll by Invisible Hand
} 
Will you, won't you, will you, won't you, put in extra time?

Will you, won't you, will you, won't you, do more for your dime?

From the perspective of today's debates over global warming and climate change, Keynes’ preference for high discount rates also strikes a peculiar chord, since it downgrades the danger that environmental change poses a major disaster to future human life. Marshall's preference for a low discount rate would seem more appropriate for a world that faces potentially catastrophic future risks, though the issue of how to evaluate such risks and the discount rate to apply is a complicated one. ${ }^{13}$ With hindsight, Keynes' underlying postulate in his essay that humanity had effectively solved the economic problem was excessively optimistic, given the ensuing impact of economic production on the environment.

One attraction of work - the intrinsic component, which Keynes presumably viewed positively as representing higher moral value -- also helps explain why his prediction of vastly reduced work hours is so far off the mark. Since work produces income, which has positive value to people, at the point where the person decides to stop working, the marginal utility of work has to be less than the marginal utility of leisure. But up to some infra-marginal point, work can be more desirable than hours of leisure, even at zero wages. Surveys that ask people about their life happiness find that unemployment is one of the major drivers of self-reported unhappiness, and one that has a larger impact than income per se. ${ }^{14}$ Many people go to work for reasons beyond money, and might prefer to work longer than Keynes' 15 hours a week under almost any situation. Workplaces are social settings, where people meet and interact. On the order of 40 to 60 percent of American workers have dated

13 The arguments about economic policies to reduce global warming hinge in large part on the choice of a social discount rate. See Nordhaus, William, "The Stern Review on the Economics of Climate Change "NBER Working Paper 12741, December 2006

${ }^{14}$ Clark A, Oswald AJ (1994) Unhappiness and Unemployment. Economic Journal 104(2): 648-659 
someone from their office. ${ }^{15}$ In the UK many persons look forward to the staff heading to a nearby pub at the end of the day. In the US and to a lesser extent in the UK many people volunteer to work for charitable causes without pay rather than lolling around the house as did the idle rich in Keynes' era. My guess is that Keynes would applaud volunteer and charitable activities as good allocations of time, had he focused on them, but his vision of a world with no economic problems precluded some of the incentives that motivate such behavior.

In any case, we grandchildren are working far more hours than Keynes expected us to do. Perhaps we are wrong in doing this. Perhaps we should strive toward Keynes's desired outcome - a more leisurely world where people reject avarice, the pursuit of economic gain, and the rat race of work. This normative view attracts diverse social critics and analysts today, for much the same reasons that it seems to have appealed to Keynes. ${ }^{16}$

At the risk of being seen as a killjoy, I have the opposite view of the normative aspect of work and leisure. Rather than bemoaning purposive behavior, I applaud the internal adjustment mechanism that leads us to take today's consumption and happiness as given and to strive for improvements. As members of a thinking species on a small planet in a giant universe with no more than 80-90 years of life, I think it is wrong to sit on our haunches and enjoy economic well-being. We are, after all, in a great race - for life against death, for knowledge against ignorance, for exploring and understanding the world around us before the Big Contraction or Crash or whatever comes next. And hard work is the only way forward. Evolution presumably imbued us with a work ethic for our survival and not for a Garden of Eden existence. That is fine with me..

\footnotetext{
${ }^{15}$ http://www.boston.com/bostonworks/news/articles/2006/10/15/office_romances_fraught_with_compl ications? mode $=\mathrm{PF}$

${ }^{16}$ Jeremy Rifkin's End of Work (Tarcher, 1996) argued for a new allocation of time. Juliet Schor The Overworked American: The Unexpected Decline of Leisure (Basic Books, 1992) also favors a Keynesian allocation of time.
} 
Keynes ended his essay by telling us that we ought not overestimate the importance of the economic problem in the face of "other matters of greater and more permanent significance", without specifying those "other matters". He hoped that as economic scarcity diminished economists would become humble, competent people, on a level with dentists. Dentistry? Talk about dismal professions. My hope for us and for our grandchildren is quite different. If by working hard and devising new incentive and market forms and advancing our understanding of economic behavior, economists can get ourselves thought of as visionary creative social scientists, on a level with entrepreneurs or science fiction writers or jazz musicians, that would be splendid! And if we can't be that cool, I'd rather be a sociologist than a dentist.

In short, thank heavens Keynes was wrong about the strength of human devotion to work. There is so much to learn and produce and improve that we should not spend more than a dribble of time living as if we were in Eden. Grand children, keep trucking. 